\title{
The Genus Enterococcus As Probiotic: Safety Concerns
}

\author{
Tatiane Ferreira Araújo* and Célia Lúcia de Luces Fortes Ferreira \\ Departamento de Tecnologia de Alimentos; Universidade Federal de Viçosa; 36570-000; Viçosa - MG - Brasil
}

\begin{abstract}
Species from the genus Enterococcus have been used as probiotic for humans or animals, although this genus is not considered "generally recognized as safe" (GRAS). While enterococci are considered "positive" in food technology, isolates of this genus have emerged as opportunistic pathogens for the humans. The aim of this review is to summarize the characteristics that can determine the use of this genus as probiotics. According to the guidelines used to define the genus Enterococcus strains as probiotic a case-by-case evaluation of each potential technological strain is presented and research perspectives for using enterococci as probiotic is also discussed.
\end{abstract}

Key words: Disease, Enterococcus, Probiotic, Safety aspects

\section{INTRODUCTION}

The genus Enterococcus belongs to the family Enterococcaceae along with the genera Atopobacter, Catellicoccus, Melissococcus, Pilibacter, Tetragenococcus and Vagococcus. (Devriese et al. 2006; Euzéby 2010). In general, the enterococci may occur in the form of isolated cocci, in pairs or in short chains. They do not produce spores, are oxidase negative and facultative anaerobe. They are classified as lactic acid bacteria (LAB) as they carry most of the phenotypes of the other components of the group such as Gram positive, catalase negative and the ability to convert glucose into lactic acid as main product (homofermentative) of primary metabolism. Moreover, individuals of this genus grow at an optimum temperature of $35{ }^{\circ} \mathrm{C}$, although some species of the genus grow in temperatures ranging from 10 to $45^{\circ} \mathrm{C}$. Most of them grow at high $\mathrm{NaCl}$ concentrations (up 6.5\%), $\mathrm{pH}$ 9.6, survive at $60^{\circ} \mathrm{C}$ for $30 \mathrm{~min}$, hence are considered thermoduric. Many of these organisms can hydrolyze esculin in the presence of $40 \%$ bile salts, which is one of the traits for phenotypic identification (Holt et al. 1994; Devriese et al. 2006; Leblanc 2006). The main species of this genus, frequently found both in food and in clinical samples, are Enterococcus faecalis and $E$. faecium (Facklam et al. 1995; Hardie and Whiley 1997). Although nowadays molecular tools are available for the identification of the strains and species of the genus, phenotype characterizations are still important in some instances, such as for the screening and for presumptive identification. Other traits to complement the phenotype characterization are carbohydrate fermentation (mannitol, sorbose, arabinose, sorbitol, raffinose), growth at 10 and $45^{\circ} \mathrm{C}$, hydrolysis of arginine (arginine decarboxylation test), metabolism of pyruvate (1\%), motility and production of yellowish pigmentation (Devriese et al. 2006).

Species of Enterococcus are ubiquitous and produce a variety of products such as aromatic compounds (Centeno et al. 1999), enzymes (Sarantinopoulous et al. 2001; Ghrairi et al. 2008) and bacteriocins (enterocins) (Cleveland et al. 2001; Achemchem et al. 2005). They contribute to

*Author for correspondence: tatianefaraujo@gmail.com 
the texture, flavor, aroma and safety of different foods as in the case of handmade cheeses (Andrighetto et al. 2001), sausages (Sabia et al. 2002; Tanasupawat et al. 2008) and other fermented products (Giraffa 2000; Bover-Cid et al. 2001; Gardini et al. 2001; Gomes et al. 2008).

The LAB have been sources of probiotic strains, which include Lactobacillus and Bifidobacterium as predominant genera (Coeuret et al. 2004). The genus Enterococcus has been the target of several studies for use as probiotics (Sivieri et al. 2008; Kuritza et al. 2011). They have some desirable characteristics for this purpose such as resistance to gastric juice and bile salts (Rossi et al. 2003) and production of antimicrobial compounds such as enterocin (Franz et al. 1999; Saarela et al. 2000).The genus has been isolated from different niches such as water (Oliveira and Pinhata 2008), plants (Svec et al. 2011), animals (Jung et al. 2007) and foods (Gomes et al. 2008) and different species have been used as starter or adjunct culture in the manufacture of fermented products such as cheese (Centeno et al. 1999; Ghairi et al. 2008; Williams and Withers 2010; Morandi et al. 2011) and sausages (Sabia et al. 2002; Tanasupawat et al. 2008), among others.Although some studies have corroborated its effectiveness as probiotic (Bellomo et al. 1980; Saavedra et al. 2001; Benyacoub et al. 2003; Rivera-Espinoza and Gallardo-Navarro 2010), others have shown correlation of the genus with diseases, which include urinary tract infections (Protonotariou et al. 2010), bacteremia (Shankar et al. 1999, Shankar et al. 2002; Tan et al. 2010) and endocarditis (Conde-Estéves et al. 2010; Rasmussem et al. 2010; Heikens et al. 2011). However, the host is usually patients with serious diseases and immuno-compromised (Brilliantova et al. 2010) what emphasizes its opportunist nature. This review aims to discuss the main virulence factors present in the genus Enterococcus which jeopardizes the safety of the genus and warrants precautions when new probiotic strains are considered.

\section{ENTEROCOCCUS AS PROBIOTIC}

Probiotics are "live microorganisms that confer a health benefit to the host when administered in adequate amounts" (FAO / WHO, 2002). Studies in the area of probiotics have advanced significantly due to the growth of interest in the products supplemented with these microorganisms. The features associated with the probiotics include maintenance of the balance of intestinal microbiota (Arvola et al. 1999), control of diarrhea (Arvola et al. 1999), stimulation of the immune system (Isolauri et al. 2004), reducing hypersensitivity to allergenic substance and eczema in children (Kalliomäki et al. 2001; Kukkonen et al. 2007), prevention of intestinal inflammations (Isolauri et al. 2000; Kalliomäki al., 2001), and modulation of undesirable effects of lactose upon non-persistent lactase individuals (Griffin et al. 2002).

Traditionally, species from the Lactobacillus and Bifidobacterium are among the major strains used as probiotics (Coeuret et al. 2004) and are carried in different foods such as yoghurt (Moschner et al. 2004), juice (Yon et al. 2006), cheeses (Gardiner et al, 1999), etc. Different strains of these genera are able to contemplate all the criteria for being considered a probiotic, such as i) belonging to the host microbiota in which the probiotic is administered, ii) stability against gastric juice and bile salts, iii) ability to adhere to the intestinal mucosa and colonize it, iv) have antagonistic effect to different pathogens, and v) stimulation of the immune system. Other key features are i) the safety for human/animal use, ii) the history of nonpathogenicity and iii) no association with other diseases such as endocarditis, iv) besides the absence of gene determinants of antibiotic resistence (Saarela et al. 2000; FAO/WHO 2002). However, some other species of bacteria and fungi such as Bacillus (Endres et al. 2011), Enterococcus (Sivieri et al. 2008), and Sacharomyces (Psomas et al, 2001) have also been used as probiotics in food and feed.

Enterococcus strains have been used as supplement for the food and feed such as poultry and swine to replace the use of sub-lethal antibiotics in the feeds. Many studies have been conducted to evaluate the effect of probiotic strains of this genus (mainly E. faecium). Generally, human studies are scarcer when compared to animal applications.

Pollmann et al (2005) obtained positive results in reducing the rate of infection by endogenous Chlamydiae in the pigs supplemented with strain Cylactin LBC ME10 (probiotic group), a microencapsulated E. faecium SF68 (NCIMB 10415), containing $9 \times 10^{9} \mathrm{CFU} / \mathrm{g}$ viable bacteria. The results showed a reduction in the 
severity of infections as well as of the number of infections caused by Chlamydiae.

Kuritza et al (2011) evaluated the effects of addition of a probiotic strain E. faecium (Cylactin ME 20 Plus $® 50 \mathrm{~g} / \mathrm{T}$ ) in the feed of chickens with the objective of controlling the contamination by Salmonella Minnesota (SM). The poultry were divided into three treatments: i) basal diet (BD); ii) BD inoculated with $108 \mathrm{CFU} / \mathrm{mL}$ of Salmonella Minnesota (SM); iii) $\mathrm{BD}+\mathrm{SM}+$ the probiotic $E$. faecium $\left(2 \times 10^{10} \mathrm{cfu} / \mathrm{g}\right)$. The results demonstrated that the use of the probiotic strain on the diet was efficient in controlling and reducing the counts of SM. Moreover, it proved to be an alternative to replace the use of antibiotics to control the pathogens.

Allen et al (1996) identified a new strain of $E$. faecium (PR88) with probiotic claim. The strain has been deposited in European Patent (Number: 0508701), claiming the benefit to relief symptoms in irritable bowel syndrome (IBS).In a study conducted by Rossi et al (2003) strains of $E$. faecium CRL 183 and Lactobacillus jugurti 416 were added in a product fermented soy-based and serum lipid levels was evaluated in normocholesterolemic adult men. The group that had received the fermented product supplemented with strains tested showed an increase of $10 \%$ in HDL cholesterol levels compared to the group that did not consume the product containing the probiotic strains.Sivieri et al. (2008) determined the effect of probiotic E. faecium CRL 183 on the incidence of colon tumors experimentally induced by dimethylhydrazine $(\mathrm{DMH})$ in Wistar rats. The rats that consumed E. faecium CRL 183 presented a $50 \%$ average inhibition as well as enhanced the immune response by increasing the IL- 4 , IFN- $\gamma$ e TNF- $\alpha$ when compared with the DMH group

Enterococcus is one of several genera found in intestinal microbiota. It competes for adhesion sites in the epithelial cells with pathogens microorganisms, thus preventing the colonization and stabilization of a microbiota unfavorable to the individual. It presents features resistance to gastric juice and bile salts, and therefore, when administered, can reach the intestine in relatively high proportions, with an additional factor in colonization it. Due to these characteristics, many strains of this genus have been studied and commercialized as probiotics (Franz et al. 1999). In Brazil, the National Agency of Sanitary Surveillance (ANVISA) defines a list of microorganism claimed as having functional properties (probiotic). The genera listed with some probiotic effect include Lactobacillus (five species), Lactococcus (one species), Bifidobacterium (three species) and Enterococcus (one species). Although E. faecium is among the probiotic strains allowed to be used as probiotic, its many strains are known for carrying virulence factors already described, which include the resistance to antibiotic as the most danagerous characteristic for a microorganism to be used as probiotic (Billstrom et al. 2008).

\section{VIRULENCE FACTORS IN ENTEROCOCCUS: PARAMETERS TO BE ASSESSED}

During the last two decades, Enterococcus has been identified as an agent of nosocomial infections with an increasing frequency; in parallel the resistance the antimicrobial agents have been increased. As a result, Enterococcus has emerged as a main challenge to doctors, when identified and associated with the principal cause of infection, especially in immunocompromised patients (Mundy et al. 2000).Substances produced by the microorganisms that can cause harm to the host are referred to as virulence factors. The term came to express any component of microorganism that is required to generate the illness or enhance it (Schaechter et al. 1999).

Enterococcus is a commensal organism that does not secrete any potentially virulent toxin, although capable of developing the disease, especially in immunocompromised patients. Infections caused by enterococci are originated from the patient's own intestinal microbiota and can be transferred from one individual to another, or can be acquired by the consumption of contaminated food and water (Murray 2006; Brilliantova et al. 2010).

This genus is often associated with the pathogenesis such as infections of the urogenital tract (Protonotariou et al. 2010) and endocarditis (Heikens et al. 2011). It is capable of transporting the antibiotic resistence genes to produce $\beta$ hemolysin (Franz et al. 2001), gelatinase (Huycke et al. 1991) and aggregation substance (Sartingen et al. 2000) that are undesirable phenotypes in probiotic strain.

\section{Antibiotic Resistance}

There are various biochemical pathways that enable the bacteria to resist to the action of 
antibiotics, which include the low intracellular accumulation of the antibiotic by altering the permeability of the external membrane, decreased transport across the inner membrane or efflux mechanisms, alteration of target by mutation or enzymatic modification and the enzymatic inactivation of the antibiotic. The coexistence of various mechanisms of antibiotic resistence in a microorganism can lead to Multi-Drug Resistance (MDR) (Depardieu et al. 2007).

Enterococcus is a common member of the endogenous intestinal microbiota. Due to the capability to acquire the resistance genes (on plasmids or transposons) from other microorganisms, it has higher probability of acquiring the resistant pathogenic markers than others in the same niche (Chopra e Roberts, 2001). Some genes that confer resistance to cephalosporins, sulfonamides and aminoglycosides are usually intrinsic, i.e., located in the chromosomes. However, some Enterococcus species may carry extrinsic resistance to chloramphenicol, erythromycin, tetracycline and vancomycin. These genes are located in the plasmids or in transposons, enabling horizontally or vertically transfer to different groups of microorganisms, such as to Streptococcus spp., Staphylococcus aureus and Bacillus subtilis, and thus hampering the antimicrobial therapy (Chow et al. 1997; Chow 2000; Donabedian et al. 2003).

\section{Vancomycin-Resistant Enterococci}

Enterococcus has different types of conjugation, which facilitates the spread of resistance genes to other species of microorganisms. These systems include plasmids that can replicate in several Gram positive bacteria, in addition to the mechanism via transposon conjugation, which can be transferred intracellularly and integrate into the genome of the host bacteria (Zarilli et al. 2005).

The high genetic diversity in Enterococcus group suggests adaptations for specific mutations in different environments. Thus, continuous exposure to antibiotics may cause a mutation that confers bacteria resistance to certain antimicrobial compound, enabling their survival. This may explain the occurrence of MDR found in the strains isolated from hospital environment (Centinkaya et al. 2000; Shepard and Gilmore 2002).

Currently, there are six known phenotypes of glycopeptide resistance $(\operatorname{van} \mathrm{A}, \operatorname{van} \mathrm{B}, \operatorname{van} \mathrm{C}, \operatorname{van} \mathrm{D}$, van $\mathrm{E}$ and $v a n \mathrm{G}$ ) in Enterococcus. The van $\mathrm{A}$ operon is characterized by the strains that present high levels of resistance to vancomycin and teicoplanin. The van $\mathrm{B}$ operon induces varying levels of resistance to vancomycin with minimal inhibitory concentration (MIC) between 4-1000 $\mathrm{mg} / \mathrm{mL}$ ). Only $\operatorname{van} \mathrm{A}$ and $\operatorname{van} \mathrm{B}$ have the capacity to transfer vertically and horizontally and to confer high levels of resistance (Centinkaya et al. 2000).

The vanA phenotype is characterized by the strains that exhibit high levels of resistance to vancomycin and teicoplanin due to the expression of genes inserted into transposon Tn1546 nonconjugative (Arthur et al. 1993)

The van $\mathrm{B}$ operon originated from transposon Tn1547 or Tn1549 induces several levels of vancomycin resistance but does not induce resistance to teicoplanin. Naturally, this gene is located on bacterial chromosome, but can be obtained from the plasmids to other organisms (Leme and Ferreira 2001).

The phenotype characterized by vanC strains shows low level resistance to vancomycin and intrinsic sensitivity to teicoplanin (Navarro andCourvalin, 1994).

The operon van $\mathrm{D}$ induces a moderate degree of resistence to vancomycin and teicoplanin and is present in chromosome and is different from other resistence genes, this trait does not seem to be transferable due to its stability in the genome (Casadewall and Courvalin, 1999).

The van $\mathrm{E}$ and $\operatorname{van} \mathrm{G}$ operons encode a low level resistence to vancomycin and are believed to be acquired and inducible (Fines et al. 1999; Mckessar et al. 2000). In the year 2000, vanG gene was detected in E. faecalis that conferred resistance moderately to teicoplanin (Centinkaya et al. 2000).

\section{Gelatinase, Cytolysins / Hemolysin and Hyaluronidase}

Gelatinase is a metalloendopeptidase capable of hydrolyzing insulin, casein, hemoglobin, fibrinogen, collagen and gelatin ( $\mathrm{Su}$ et al. 1991). The cytolysin is a protein with bacteriocin / hemolysin bifunctionality (Mundy et al. 2000). Hyaluronidase causes the lysis of the hyaluronic acid, which is the main part of the connective tissue of the extracellular matrix.

These virulence factors are found in almost all the species of Enterococcus but their expression depends on the niche of isolation. It has been shown that $\beta$-hemolytic strains of Enterococcus 
increased five times the chance of death caused by the bacteremia when compared to the patients with bacteremia caused by non- $\beta$-hemolytic strains (Huycke et al. 1991). Strains of E. faecium and E. faecalis have demonstrated the ability to synthesize this protease due to the presence of the gelE gene which may be present but not expressed (Kanemitsu 2001). Often, Enterococcus is considered major hospital pathogen causing bacteremia, endocarditis and urinary tract infections. However, it has been established that it could be seen as an opportunistic pathogen to the patients with serious illnesses and immunocompromised (Murray 1990). Special focus is given on the resistance of Enterococcus to vancomycin, the latest antibiotic developed for the treatment of enterococcal infections that cannot be treated with the conventional antibiotic therapy. This consideration alone warrants precaution in the choice of a probiotic strain belonging to this genus.

In E. faecalis, cytolysin is active against a wide range of Gram-positive bacteria, and also smooth cells, both prokaryotic and eukaryotic, with activity against horse, rabbit and human erythrocytes, but has no action on sheep erythrocytes (Gilmore et al. 1990). The relative $c y l$ operon expression of cytolysin can be found in self-transmissible plasmids, integrated into the chromosome and also in pathogenicity islands (PAI). It is often associated with other virulence factors (Shankar et al. 2002).

Hyaluronidase is a hydrolytic enzyme, encoded by the gene hyl (Kayaoglu and Orstavik, 2004). It is the main part of the connective tissue extracellular matrix and its destruction caused the breaking of the tissue which facilitates the spread of microorganisms within the tissue (Hynes and Walton 2000). The percentage of infectious diseases caused by E. faecium has increased among the infections caused by Enterococcus in the United States in the last decade, and this has been suggested as caused by the increase of the virulence of the genus which includes the high incidence of orf linked to hyaluronidase (Rice et al. 2003).

\section{Adhesins}

In an infectious process, the first step that occurs in tissue colonization by the microorganisms is adherence of the pathogen in adjacent cells. In the strains with probiotic function, adhesion is an important features that favors the colonization and establishment of beneficial microbiota in the intestinal tract (Ferreira et al, 2011). Among the substances that promote this adherence are adhesins. These substances are formed by small peptide molecules, composed of seven to eight amino acids that promote the adhesion of the bacterial cell to host tissue (Nallapareddy et al, 2003). They have been identified a frequency of up to $60 \%$ by strains of E. faecalis isolated from different outbreaks (Mundy et al. 2000). The various substances with the function of assisting in the adhesion process include the aggregation substances and surface proteins.

\section{Aggregation substance}

Aggregation substance (AS) is a virulence factor which appears to mediate the specific binding to the intestinal epithelium, renal epithelial cells, human neutrophils and macrophages (Sussmuth et al. 2000).

An adhesion called Acm, has been identified in $E$. faecium. This adhesin binds to the collagen type I and is part of the subfamily of bacterial adhesins surface denominated Microbial Surface Components Recognizing Adhesive Matrix Molecules (MSCRAMM) which binds specifically to the protein layer of the extracellular matrix of the host. MSCRAMM adhere to the collagen, fibronectin, fibrinogen and / or laminin host tissue exposed after being injured. Adhesins help in the host tissue colonization while other proteins aid in the evasion of host defenses and can therefore, lead to infection (Nallapareddy et al. 2003).

\section{Enteroccal surface protein}

The virulence factor associated with the presence of surface protein (Esp) seems to be involved in the process of cell-cell adhesion. The gene responsible for the expression of the protein Esp is located in a highly conserved chromosome region within the genus, and is common in the strains of E. faecium sensitive or resistant to vancomycin (Shankar et al. 2002). This protein has several regions involved in the adhesion to eukaryotic cells and immune response evasion.

Waar et al. (2002) observed that the surface protein of E. faecalis promotes the adhesion of bacteria to bile drain materials (silicone rubber, fluoro-ethylene-propylene and polyethylene). The results indicated that when the gene expression occurred, it resulted in an increase in the frequency of adhesion of the cells to the materials evaluated. 
Thus, there is a higher biofilm formation even more firmly adhered to drainage materials.

\section{Pathogenicity Islands}

Another recent finding in this genus is the presence of pathogenicity islands (PAI). The PAI of Enterococcus was first identified in the genome of multi-drug-resistant strain of $E$. faecalis MMH594, a clinical specimen that had caused an outbreak of nosocomial infection in the 1980's (Huycke et al. 1991). The strain MMH594 found in this gene encodes 129 Open Reading Frames (ORF) and has characteristics such as size equal to $150 \mathrm{~kb}$, terminal duplication of target site, the $\mathrm{G}+\mathrm{C}$ lower than the rest of the genome of Enterococcus (32.2\%) and shows transposases, genes encoding transcriptional regulators signs or adaptation and survival in different environments (Shankar et al. 2002). Virulence genes found in this element are among others esp gene, cyt operon, asc 10 (gene for aggregation substance), gls24-like (protein gene inducible by stress). All these genes contribute to bacterial aggregation, survival in the activity of neutrophils and adherence to host tissue (Shankar et al. 2002).

The process of transference and acquisition of this mobile element is unknown (Hacker et al. 2000). Several studies have been conducted in order to evaluate how the transfer of these PAIs occurs between the microorganisms, as well as the relationship between the presence of virulence genes with the presence / size of the islands.

The strain E. faecalis vancomycin-resistant V583 has its genome fully sequenced and it was observed that over $25 \%$ were related to mobile elements which included a PAI (Paulsen et al. 2003). Therefore, the possibility of antimicrobial resistance genes or genes that encode virulence factors to be transferred to other bacteria in the gastrointestinal tract warrants evaluation of the practice of using species from this genus as probiotic.

\section{CONCLUSION}

Enterococci have long been presented in numerous fermented products, but their applications as probiotic are still debated due to the genus containing species and strains etiologically involved in diseases (Shankar et al. 1999, 2002; Conde-Esteves et al. 2010; Rasmussen et al. 2010, Tan et al. 2010; Heikens et al. 2011) and in the risks of transfer of antimicrobial resistance and virulence genes to human strains.

The rapid acquisition of antimicrobial among enterococci and other species probably contributes to their emergence as prominent nosocomial pathogens. Some strains are resistent to many antibiotics and possess virulence factors such as adhesins and haemolysin, often located on pathogenicity islands or plasmids. Mobile genetic elements are thus considered to play a major role in the establishment of problematic lineages. These virulence genes could be transferred to human endogenous strains present in the gastrointestinal tract, which could contribute in increasing the virulence factors of this genus and endogenous strains.

In humans, studies about the probiotics (administered Enterococcus strains) have been conducted for the treatment of diarrhea, antibioticassociated diarrhea or irritable bowel syndrome, to lower the cholesterol levels or to improve host immunity. In the animals, enterococcal probiotics are mainly used to treat or prevent diarrhea and to improve the growth.

Therefore, the safety of the enterococcal strains used as probiotics must be assured, and the advantages of using these and new strains should be considered in a well contemplated risk/benefit analysis.

\section{REFERENCES}

Achemchem F, Martinez-Bueno, M, Abrini, J, Valdivia, E, Maqueda, M. Enterococcus faecium F58, a bacteriocinogenic strain naturally occurring in Jben, a soft, farmhouse goat's cheese made in Morocco. J Appl Microbiol. 2005; 99: 141-150.

Allen WD, Linggood MA, Porter P. Enterococcus organisms and their use as probiotics in alleviating irritable bowel syndrome symptoms. European Patent 0508701 (B1), 1996.

Andrighetto C, Knijff E, Lombardi A, Torriani S, Vancanneyt M, Kersters K. et al. Phenotypic and genetic diversity of enterococci isolated from Italian cheeses. J Dairy Res. 2001; 68: 303 - 316.

ANVISA - Brazilian Agency of Sanitary Surveillance. Food with health claims, new foods/ingredients, bioactive compounds and probiotics. http://www.anvisa.gov.br/alimentos/comissoes/tecno _ lista_alega.htm. Accessed Nov 28, 2011.

Arthur M, Molinas C, Courvalin P. Sequence of the vanY gene required for production of a vancomycininducible D,D-carboxypeptidase in Enterococcus faecium BM4147. Gene. 1992; 120:111-114. 
Arvola, T, Laiho K, Torkkeli S, Mykkanen H, Salminen S, Maunula L, Isolauri E. Prophylactic Lactobacillus $G G$ reduces antibiotic associated diarrhea in children with respiratory infections: a randomized study. Pediatrics. 1999; 104(5): 1121-1122.

Bellomo G, Mangiagle A, Nicastro L, Frigerio G. A controlled double-blind study of SF68 strain as a new biological preparation for the treatment of diarrhoea in pediatrics. Curr Ther Res. 1980; 28: 927-936.

Benyacoub J, Czarnecki-Maulden GL, Cavadini C, Sauthier T, Anderson RE, Schiffrin et al. Supplementation of food with Enterococcus faecium (SF68) stimulates immune functions in young dogs. J Nutr. 2003; 133:1158- 1162.

Billström H, Lund B, Sullivan A, Nord CE. Virulence and antimicrobial resistence in clinical Enterococcus faecium. Int J Antimicrob Agent. 2008; 32: 374-377.

Bover-Cid S, Hugas M, Izquierdo-Pulido M, VidalCarou MC. Amino acid-decarboxylase activity of bacteria isolated from fermented pork sausages. Int $\mathbf{J}$ Food Microbiol. 2001; 66: 185-189.

Brilliantova AN, Kliasova GA, Mironova AV, Tishkov VI, Novichkova, GA, Bobrynina VO et al. Spread of vancomycin-resistant Enterococcus faecium in two haematological centres in Russia. Int $\mathbf{J}$ Antimicrob Agents. 2010; 35: 177-181.

Casadewall B, Courvalin P. Characterization of the vanD glycopeptide resistence gene cluster from Enterococcus faecium BM4339. J Bacteriol. 1999; 181: 3644-3648.

Centeno JA, Menendez S, Hermida MA, RodriguezOtero JL. Effects of the addition of Enterococcus faecalis in Cebreiro cheese manufacture. Int J Food Microbiol. 1999; 48: 7-111.

Centinkaya Y, Falk P, Mayhall G. Vancomycinresistant enterococci. Clin Microbiol Rev. 2000; 13: 686-707.

Cleveland J, Montville TJ, Nes IF, Chikindas ML. Bacteriocins: safe natural antimicrobials for food preservation. Int J Food Microbiol. 2001; 71(1): 120.

Coeuret V, Gueguen M, Vernoux JP. Numbers and strains of lactobacilli in some probiotic products. Int $\mathbf{J}$ Food Microbiol. 2004; 97: 147-56.

Chopra I, Roberts M. Tetracycline antibiotics: mode of action, applications, molecular biology, and epidemiology of bacterial resistence. Microbiol Mol Biol Rev. 2001; 65: 232-260.

Chow JW. Aminoglicoside resistence in Enterococci. Clin Infect Dis. 2000; 31: 586-589.

Chow JW, Zervos MJ, Lerner SA, Thal LA, Donabedian SM, Jaworski DD et al. A novel gentamicin resistence gene in Enterococcus. Antimicrob Agents Chemother. 1997; 41: 511-514.

Conde-Estévez D, Sorli L; Morales-Molina JA, Knobel H, Terradas R, Mateu-de Antonio J. et al. Características clínicas diferenciales entre las bacteremias por Enterococcus faecalis $y$
Enterococcus faecium. Enferm Infec Micr Cl. 2010; 28(6):342-348.

Depardieu F, Leclercq R, Collatz E, Courvalin P. Modes and modulations of antibiotic resistence gene expression. Clin Microbiol Rev. 2007; 20: 79-114.

Devriese L, Baele M, Butaye P. The genus Enterococcus: Taxonomy. In: M. Dworkin, S. Falkow, E. Rosenberg, K-H. Schleifer and E. Stackebrandt. The Prokaryotes: a Handbook on the Biology of Bacteria. 3rd edn. New York: Springer. vol. 4; 2006. 163-174.

Eaton, TJ, Gasson M. Molecular screening of Enterococcus virulence determinants and potential for genetic exchange between food and medical isolates. Appl Environ Microbiol. 2001; 67: 16281635.

Endres JR, Qureshi I, Farber T, Hauswirth J, Hirka G, Pasics I et al. One-year chronic oral toxicity with combined reproduction toxicity study of a novel probiotic, Bacillus coagulans, as a food ingredient. Food Chem Toxicol. 2011; 49(5): 1174-1182.

Euzeby JP. List of Prokaryotic names with Standing in Nomenclature. Toulouse: Université Paul Sabatier. Available from:

http://www.bacterio.cict.fr/e/enterococcus.html. Updated in 11 nov. 2010.

Facklam RR, Sahm DF. Enterococcus. In: Murray PR, Bacon ET, Pfaller MA, Tenoven FC, Yolken RH. Manual of clinical microbiology. Washington: ASM Press; 1995. p. 308-314.

FDA. US Food and Drug Administration. Direct-fed microbial products. Section 698.100. Revised March. 1995. Available at: http://www.fda.gov/ora/compliance_ref/cpg/cpgvet/c pg689-100.html. Accessed 18 Oct 2011.

Ferreira CLLF, Grzeskowiak L, collado MC, Salminen SJ. In vitro evaluation of Lactobacillus gasseri strains of infant origin for adhesion and aggregation of specific pathogens. J Food Prot. 2011; 74: 1482-1847.

Food and Agriculture Organization of the United Nations, World Health Organization. Guidelines for the Evaluation of Probiotics in Food. Ontario: Joint FAO/WHO Working Group Report on Drafting London Canada, 2002.

Fines M, Perichon B, Reynolds P, Sahm DF, Courvalin P. VanE, a new type of acquired glycopeptide resistence in Enterococcus faecalis BM4405. Antimicrob Agents Chemother. 1999; 43: 21612164.

Franz CMAP, Holzapfel WH, Stiles ME. Enterococci at the crossroads of food safety? Inter J Food Microbiol. 1999; 47:1 -24.

Furumura MT, Carbonell GV, Lemes-Marques EG, Darini ALC, Yano T. Características de hemolisina termo-estável produzida por Enterococcus faecalis provenientes de infecção hospitalar. IN: XXI Congresso Brasileiro de Microbiologia: 2001 Out; Foz do Iguaçu, Brasil. Foz do Iguaçu, Sociedade 
Brasileira de Microbiologia: SBM, 2001. p.113, MH226. (Abstract).

Gardini F, Martuscelli M, Caruso MC, Galgano F, Crudele MA, Favati $F$ et al. Effects of $\mathrm{pH}$, temperature and $\mathrm{NaCl}$ concentration on the growth kinetics, proteolytic activity and biogenic amine production of Enterococcus faecalis. Int. J. Food Microbiol. 2001; 64: 105-117.

Gardiner G, Ross RP, Wallace JM, Scanlan FP, Jagers PJM, Fitzgerald GF et al. Influence of a probiotic adjunct culture of Enterococcus faecium on the quality of cheddar cheese. J Agric Food Chem. 1999a. 47(12): 4907-4916,

Gardiner G, Stanton C, Lynch PB, Collins JK, Fitzgerald G, Ross RP. Evaluation of cheddar cheese as a food carrier for delivery of a probiotic strain to the gastrointestinal tract. J Dairy Sci.1999b; 82: 1379-1387.

Ghrairi T, Frere J, Berjeaud JM, Manai M. Purification and characterization of bacteriocins produced by Enterococcus faecium from Tunisian Rigouta cheese. Food Control. 2008; 19: 162 -169.

Gilmore MS, Segarra RA, Booth MC. An HlyB-type function is required for expression of the Enterococcus faecalis hemolysin/bacteriocin. Infect Immun. 1990; 58: 3914-3923.

Giraffa, G., Olivari, A.M., Neviani, E. Isolation of vancomycin-resistant Enterococcus faecium from Italian cheeses. Food Microbiol. 2000; 17: 671-677.

Gomes BC, Esteves CT, Palazzo ICV, Darini ALC, Felis GE, Sechi LA. Prevalence and characterization of Enterococcus spp. isolated from Brazilian foods. Food Microbiol. 2008; 25: 668-675.

Griffin IJ, Davila PM, Abrams SA. Non-digestible oligosaccharides and calcium absorption in girls with adequate calcium intakes. Bri J Nutr. 2002; 87(2): S187-S191.

Hacker J, Kaper JB. Pathogenicity islands and the evolution of microbes. Annu Rev Microbial. 2000; 54: 641-79.

Hardie JM, Whiley RA. Classification and overview of the genera Streptococcus and Enterococcus. Soc Appl Bacteriol Symp Ser. 1997; 26: 1S - 11S.

Heikens E, Bonten MJM, Willems RJL. Enterococcal surface protein Esp is important for biofilm formation of Enterococcus faecium E1162. J Bacteriol. 2007; 189:8233-8240.

Holt JG et al. Bergey's manual of determinative bacteriology. 9 ed. Baltimore: Willians \& Wilkins, 1994. $787 \mathrm{p}$.

Huycke MM, Spiegel CA, Gilmore MS. Bacteremia caused by hemolytic, high-level gentamycin-resistant Enterococcus faecalis. Antimicrob Agents Chemother. 1991; 35:1626-1634.

Hynes WL, Walton SL. Hyaluronidases of Grampositive bacteria. Microbiol Lett. 2000; 183:201-207.

Isolauri E, Salminen S, Ouwehand AC. Probiotics. Best Pract Res Clin Gastroent. 2004; 18(2): 299-313
Isolauri E, Arvola T, Sutas Y, Moilanen E, Salminen S. Probiotics in the management of atopic eczema. Clin Exp Allergy. 2000; 30: 1604-10.

Kalliomaki M, Salminen S, Arvilommi H, Kero P, Koskinen P, Isolauri E. Probiotics in primary prevention of atopic disease: A randomised placebocontrolled trial. Lancet. 2001; 357: 1076-9.

Kanemitsu K, Nishino T, Kunishima H, Okamura N, Takemura H, Yamamoto $\mathrm{H}$ et al. Quantitative determination of gelatinase activity among enterococci. J Microbiol Methods. 2001; 47:11-16.

Kukkonen K, Savilahti E, Haahtela T, JuntunenBackman K, Korpela R, Poussa T, et al. Probiotics and prebiotic galacto-oligosaccharides in the prevention of allergic diseases: a randomized, doubleblind, placebo-controlled trial. J Allergy Clin Immunol. 2007; 119(1): 192-198.

Kuritza LN, Pickler L, Miglino LB, Westphal P, Lourenço MC, Toledo M et al. Probióticos a base de Enterococcus faecium NCIMB 10415 no controle da Salmonella Minnesota em frangos de corte. In: XXII Congresso Latino Americano de Aves, Buenos Aires. Argentina 2011 (Abstract).

Laverde-Gomez JA, Hendrickx APA, Willems RJ, Top J, Sava I, et al. (2011) Intra- and interspecies genomic transfer of the Enterococcus faecalis pathogenicity island. PLoS ONE 6(4): e16720. doi:10.1371/journal.pone.0016720

Leavis H, Top J, Shankar N, Borgen K, Bonten M, Embden JV, Willems RJ L. Novel putative enterococcal pathogenicity island linked to the esp virulence gene of Enterococcus faecium and associated with epidemicity. J Bacteriol. 2004; 186:672-682.

Leblanc DJ. Enterococcus. In: M. Dworkin, S. Falkow, E. Rosenberg, K-H. Schleifer and E. Stackebrandt. The Prokaryotes: a Handbook on the Biology of Bacteria. 3rd edn. New York: Springer. vol. 4; 2006. 175-204.

Leme IL, Ferreira AJP. 2001 Enterococcias. In: Ferreira AW, Ávila SL (Eds) Diagnóstico Laboratorial das Principais Doenças Infecciosas e Auto-Imunes. Rio de Janeiro: Guanabara Koogan 2th ed; 2001. p. 132146.

Mckessar SJ, Berry AM, Bell JM, Turnidge JD, Paton JC. Genetic characterization of vanG, a novel vancomycin resistence locus of Enterococcus faecalis. Antimicrob Agents Chemother. 2000. 44: 3224-3228.

Morandi S, Cremonesi P, Povolo M, Brasca M. Enterococcus lactis sp. nov., from Italian raw milk cheeses. Int J Syst Evol Microbiol. 2011; 62: 19921996.

Moschner DLO, Jahreis G, Rechkemmer G, Pool-Zobel BL. Dietary intervention with the probiotics Lactobacillus acidophilus 145 and Bifidobacterium $l$ ongum 913 modulates the potential 
human faecal water to induce damage in HT29 clone 19A cells. Br J Nutr. 2004; 91: 925-932.

Mundy LM, Sahm DF, Gilmore, M. Relationships between enterococcal virulence and antimicrobial resistence. Clin Microbiol Rev. 2000; 13(4):513-522.

Murray PR, Rosenthal KS, Pfauer M. Microbiologia médica. Madrid. 5. ed. Elsevier, 2006.

Murray BE, Rice LB. The enterococci: pathogenesis, molecular biology, and antibiotic resistence. Washington: ASM Press; 2002. p. 1-9.

Nallapareddy SR, Weinstock GM, Murray BE. Clinical isolates of Enterococcus faecium exhibit strainspecific collagen binding mediate by Acm, a new member of the MSCRAMM family. Mol Microbiol. 2003; 47:1733-1747.

Navarro F, Courvalin P. Analysis of genes encoding Dalanine- D-alanine ligase-related enzymes in Enterococcus casseliflavus and Enterococcus flavescens. Antimicrob Agents Chemother. 1994; 38: 1788-1793.

Oancea C, Klare I, Witte W, Werner G. Conjugative transfer of the virulence gene esp, among isolates of Enterococcus faecium and Enterococcus faecalis. J Antimicrob Chemother. 2004; 54:232-235.

Oliveira AJFC, Pinhata, JMW. Antimicrobial resistence and species composition of Enterococcus spp. isolated from waters and sands of marine recreational beaches in Southeastern Brazil. Water Res. 2008; 42:2242-2250.

Paulsen IT, et al. Role of mobile DNA in the evolution of vancomycin-resistant Enterococcus faecalis. Science. 2003; 299:2071-2074.

Pollmann M, Nordhoff M, Pospischil A, Tedin K, Wieler LH. Effects of a probiotic strain of

Enterococcus faecium on the rate of natural Chlamydia infection in swine. Infect Immun. 2005; 74(7): 43464353.

Protonotariou E, Dimitroulia E, Pournaras S, Pitiriga V, Sofianou D, Tsakris A. Trends in antimicrobial resistence of clinical isolates of Enterococcus faecalis and Enterococcus faecium in Greece between 2002 and 2007. J Hosp Infect. 2010; 1-3.

Psomas E, Andrighetto C, Litopoulou-Tzanetaki E, Lombardi A, Tzanetakis N. Some probiotic properties of yeast isolates from infant faeces and feta cheese. Int J Food Microbiol. 2001; 69: 125-133.

Rasmussen M, Johansson D, Söbirk SK, Mörgelin M, Shannon O. Clinical isolates of Enterococcus faecalis aggregate human platelets. Microbes Infect. 2010; 12(4): 295-301.

Rice LB, Carias L, Rudin S, Vael C, Goossens H, Konstabel $\mathrm{C}$ et al. A potential virulence gene, hylefm, predominates in Enterococcus faecium of clinical origin. J Infect Di. 2003; 187:508-512.

Rivera-Espinoza Y, Gallardo-Navarro Y. Non-dairy probiotic products. Food Microbiol. 2010; 27(1):1-11.

Rossi EA, Vendramine RC, Carlos IZ, Oliveira MG, Valdez GF. Efeito de um novo produto fermentado de soja sobre lípides séricos de homens adultos normocolesterolêmicos. Arch Latin Nutr. 2003; 53: 47-5.

Saarela M., Mogensen G., Fonden R., Matto J. and Matilla S. T. Probiotic bacteria: Safety, functional and technological properties. J Biotechnol. 2000; 84: 197-215.

Saavedra L. Clinical applications of probiotic agents. Am J Clin Nutr. 2001;73:1147S- 1151S.

Sabia C, Manicardi G, Messi P, Niederhausem S, Bondi M. Enterocin $416 \mathrm{~K} 1$, an antilisterial bacteriocin produced by Enterococcus casseliflavus IM $416 \mathrm{~K} 1$ isolated from Italian sausages. Int $\mathrm{J}$ of Food Microbiol. 2002; 75(1-2): 163-170.

Sarantinopoulos P, Andrighetto C, Georgalaki MD, Rea MC, Lombardi A, Cogan TM, et al. Biochemical properties of enterococci relevant to their technological performance. Int Dairy J. 2001; 11:621-647.

Sartingen S, Rozdzinski E, Muscholl-Silberhorn A, Marre R. Aggregation substance increases adherence and internalization, but not translocation, of Enterococcus faecalis through different intestinal epithelial cells in vitro. Infect Immun. 2000; 68: 6044-6047.

Schaechter M, Engleberg NC, Eisenstein BI, Medoff G. Mechanisms of microbial disease. 3ed. Baltimore: Lippincott, Williams \& Wilkins; 1999.

Semedo T, Santos MA, Martins P, Lopes MFS, Marques JJF, Tenreiro R, et al.. Comparative study using type strains and clinical and food isolates toexamine hemolytic activity and occurrence of the cyl operon in enterococci. J Clin Microbiol. 2003; 41(6): 2569-2576.

Shankar, N, Baghdayan AS, Willems R, Hammerum AM, Jensen LB. Presence of pathogenicity island genes in Enterococcus faecalis isolates from pigs in Denmark. J Clin Microbiol. 2006; 44: 4200-4203.

Shankar V, Baghdayan AS, Gilmore M. Modulation of virulence within a pathogenicity island in vancomycin-resistant Enterococcus faecalis. Nature, 2002; 417: 746-750

Shankar V, Baghdayan AS, Huycke MM, Lindahl G, Gilmore M. Infection derived Enterococcus faecalis strains are enriched in esp, a gene encoding a novel surface protein. Infect Immun. 1999; 67:193-2000.

Shepard BD, Gilmore MS. Antibiotic-resistant enterococci: mechanisms and dynamics of drug introduction and resistence. Microbes Infect. 2002; 4:215-224.

Sivieri K, Spinardi-Barbisan ALT, Barbisan LF, Bedani R, Pauly N D., Carlos IZ. et al. Probiotic Enterococcus faecium CRL 183 inhibit chemically induced colon cancer in male Wistar rats. Eur Food Res Technol. 2008; 228(2): 231-237.

Svec P, Vandamme P, Bryndová H, Holochová P, Kosina M, Maslanová I, Sedlácek I. Enterococcus 
plantarum sp. nov., isolated from plants. Int J Sys Evol Microbiol. 2011; 62: 1499-505.

Su YA, Sulavik MC, He P, Makinen KK, Ma kinen P, Fiedler $\mathrm{S}$ et al. Nucleotide sequence of the gelatinase gene (gelE) from Enterococcus faecalis subsp. liquefaciens. Infect Immun. 1991; 59:415- 420.

Sussmuth SD, MuscholL-Silberhorn A, Wirth R, Susa M, Marre R, Rozdinski E. Aggregation substance promotes adherence, phagocytosis, and intracellular survival of Enterococcus faecalis with human macrophages and suppresses respiratory burst. Infect Immun. 2000; 68(9):4900-4906.

Tan CK, Lai CC, Wang JY, Lin S H, Liao CH, Huang YT, Wang CY, Lin HI, Hsueh PR. Bacteremia caused by non-faecalis and nonfaecium enterococcus species at a Medical center in Taiwan, 2000 to 2008 J. Infect. 2010; 61 (1): 34- 43

Tanasupawat S, Sukontasing S, Lee JS. Enterococcus thailandicus sp. nov., isolated from fermented sausage ("mum") in Thailand. Int J Syst Evol Microbiol. 2008; 58: 1630-1634.

Verdenelli MC, Ghelfi F, Silvi S, Orpianesi C, Cecchini C, Cresci A. Probiotic properties of Lactobacillus rhamnosus and Lactobacillus paracasei isolated from human feces. Eur J Nut. 2009; 48: 355-363.
Yoon KY, Woodams EE, Hang YD. Production of probiotic cabbage juice by lactic acid bacteria. Bio resour Technol. 2006; 97(12): 1427-1430.

Waar K, Van Der Mei HC, Harmsen JMH, Degener JE, Busscher H J. Enterococcus faecalis surface proteins determine its adhesion mechanism to bile drain materials. Microbiol, 2002; 148:1863-70.

Williams AG, Withers SE. Microbiological characterization of artisanal farmhouse cheeses manufactured in Scotland. Int J Dairy Techn. 2010; 63(3): 356-369.

Zarrili R, Tripodi MF, Podolo AD, Fortunato R, Bagattini M, Crispino $\mathrm{M}$ et al. Molecular epidemiology of high-level aminoglycoside-resistant enterococci isolated from patients in a University hospital in southern Italy. J Antimicrob Chemoter. $2005 ; 56: 827-835$.
Received: February 02, 2012; Revised: October 05, 2012; Accepted: May 02, 2013. 